\title{
Normal delivery and cesarean section: cost per brazilian regions, 2015
}

Caroline Dalmoro ${ }^{1}$

Roger Rosa ${ }^{1}$

Ronaldo Bordin ${ }^{1}$

1. Universidade Federal do Rio Grande do Sul, Social Medicine Department, Porto Alegre, RS, Brasil

\section{SUMMARY}

OBJECTIVE: To describe the number of funds made by the Brazilian National Health System to normal delivery and cesarean procedures, according to the Brazilian regions in 2015, and estimate the cost cutting if the recommendation concerning the prevalence of cesarean deliveries by the World Health Organization (10 to 15\%) were respected.

METHODS: Secondary analysis of data from the Hospital Information System of the Brazilian National Health System. The variables considered were the type of delivery (cesarean section and normal), geographic region of admission, length of stay and amount paid for admission in 2015.

RESULTS: In the year 2015, there were 984,307 admissions to perform labor in the five Brazilian regions, of which 36.2\% were cesarean section. The Northeast and Southeast regions were the two regions that had the highest number of normal deliveries and cesarean sections. The overall average hospital stay for delivery was 3.2 days. About R\$ 650 million (US\$208,5 million) were paid, 45\% of the total in cesarean deliveries. If the maximum prevalence proposed by the World Health Organization (WHO) were considered, there would be a potential reduction in spending in the order of $R \$ 57.7$ million (US\$ 18,5 million).

CONCLUSIONS: Cesarean sections are above the parameter recommended by the WHO in all Brazilian regions. The Northeast and Southeast had the highest total number of normal and cesarean deliveries and thus the greatest potential reduction in estimated costs (69.6\% of all considered reduction).

KEYWORDS: Health Policy, Planning and Management. Public Health Policy. Health economics. Natural childbirth. Cesarean section.

\section{INTRODUCTION}

Cesarean sections have become increasingly common in industrialized and developing countries. Faúndes and Cecatti ${ }^{1}$ warned about of the increased incidence of cesarean sections in Brazil in the early 1990s: from $14.6 \%$ in 1970 to $31 \%$ in the 1980 s. At that time, they showed to be a phenomenon common to almost all countries of the world, but in no other country the increasing curve was so accentuated and the rates had reached levels as high as in Brazil. Two decades after, the surgical practice (cesarean section) reached $85 \%$ of births in private hospitals and $40 \%$ in the public health system².

Some factors contributed to the increase in these taxes, such as the evolution of surgical and anesthetic techniques, the risk of immediate postoperative complications reduction, defensive obstetric practice, health system characteristics, and remuneration, as well as the patients' demand ${ }^{3}$. As regards the demand of patients, Resolution 2.144 / 2016 of the Federal Council of Medicine ${ }^{4}$ states that "It is ethical the

DATE OF SUBMISSION: 31-Dec-2017

DATE OF ACCEPTANCE: 16-Feb-2018

Corresponding Author: Ronaldo Bordin

Ramiro Barcelos, 2400, 5a andar, sala 507, Porto Alegre, RS, Brasil - CEP 90035-003

Tel/Fax: +55 (51) 3308-5327

E-mail: ronaldo.bordin@ufrgs.br 
doctor to meet the will of the pregnant woman to perform cesarean section, guaranteed the autonomy of the physician, the patient and the safety of the mother and neonate", but only after 39 weeks of pregnancy.

An indicator used to evaluate the delivery care model is the cesarean section rate. According to the normative standard of the World Health Organization (WHO), this rate should not exceed $15 \%$, a level lower than the Brazilian. The high prevalence of cesarean sections in Brazil does not seem related to changes in obstetric risk but to socioeconomic and cultural factors, especially the controversial phenomenon of "culture of cesarean section"

Faúndes and Cecatti" point out that "in developed countries, $1 \%$ increase in cesarean section rates is an extra expense of US\$9,5 million" 6 . It was estimated for Brazil in 2006, for an amount of 560,000 cesarean sections performed without a real need per year, an equivalent to R\$ 84 million (US\$ 38,7 million).

Several actions have been taken by the Ministry of Health, in partnership with the National Regulatory Agency for Private Health Insurance and Plans (ANS) in order to sustain normal birth and reduce cesarean sections in public and private service. Below, there are examples of these actions, among others: (a) Delivery Suitable Pilot Project, for the purpose of changing the delivery care model, promoting normal birth, calling assistance services during labor, delivery and postpartum, favoring the reduction of unnecessary cesareans and possible adverse events resulting from an inadequate delivery ${ }^{7}$; (b) Normative Resolution No. 368, with measures to ensure the beneficiaries of health plans the percentage of cesarean surgery standards and pregnant card ${ }^{8}$; and (c), the Pregnancy Care Guidelines Protocol: a cesarean section in order to guide women, health professionals and managers on issues related to the delivery routes, their statements and conducts, based on the best available scientific evidence ${ }^{2}$.

In 2015, there were 2,211,997 hospitalizations for pregnancy, childbirth and postpartum in women between 10 and 59 years in Brazil, representing $51.2 \%$ of total admissions. Out of these, 984,307 corresponded to vaginal delivery or cesarean section ${ }^{9}$. In this context, the aim of this article is to describe the number of funds paid by Brazilian National Health System (SUS, in Portuguese) to normal delivery and cesarean procedures, according to the five geographical regions in 2015; and to estimate the cost cutting if the WHO recommendation regarding the prevalence of cesarean sections were considered.

\section{METHODS}

This study is a descriptive and quantitative approach and using secondary data of all hospitalizations in the country, available in the Hospital Information System of the Brazilian National Health System (SIH /SUS). The five geographic regions considered in the study were North, Northeast, Midwest, Southeast, and South. The variables considered for 2015 were: Type of delivery (cesarean section and normal birth), geographic region, days of hospital stay and the amount paid by the SUS.

The tool "Tabnet", provided by the Ministry of Health, was used for data collection of hospital procedures and place of occurrence, in the year 2015. The following hospital procedures were selected: "cesarean delivery”, "cesarean delivery in high-risk pregnancy" and "cesarean section with tubal sterilization"; "normal delivery", "normal delivery in high-risk pregnancy" and "normal delivery in normal delivery center". Cesarean delivery was defined as the surgical procedure that includes abdominal incision for extracting the fetus from the maternal womb, during labor ${ }^{10}$. Normal labor starts spontaneously, remaining thus throughout the process, until birth. The baby is born spontaneously in head position, between 37 and 42 completed weeks of gestation ${ }^{11}$.

Values in R\$ were converted to US\$ by the rate of the annual mid-point (the exchange value of July $1^{\text {st }}$ of the respective year).

The management of data used descriptive statistics (frequency and average).

By employing secondary data from public domain databases, there was no need for referral to the Ethics Committee.

\section{RESULTS}

In 2015, 984,307 hospitalizations for delivery were recorded in the five Brazilian regions. Of this total, $63.8 \%$ were normal deliveries and $36.2 \%$ cesarean births (Table 1). The Northeast and Southeast regions were the ones that showed the highest percentage of normal deliveries in 2015 , with $37 \%$ and $33 \%$ of the total, respectively. Regarding the total number of cesarean deliveries, the scene is the same: the Northeast and Southeast regions were the regions with the highest quantity of cesarean deliveries (36\% and 30\% of the total, respectively). However, when comparing the percentage of cesarean deliveries, regions Mid- 
west and South have the highest levels (43\% and 39\%, respectively).

The average hospital stay for delivery in 2015 ranged from 1.6 days (northern region) and 3.1 days (Southeast) for normal deliveries and 3.1 days (Southeast) to 4.0 days (Midwest) for cesarean births, with an overall average of 3.2 days for the country.

In 2015, SUS spent R\$650,2 million (US\$ 208.5 million) in hospitalizations for childbirth. Of the total amount spent in the five Brazilian regions, $54.9 \%$ was allocated to admissions for deliveries of the normal type and $45.1 \%$ for deliveries of cesarean section type (Table 2).

To obtain an estimate of costs, respecting the levels recommended by WHO for cesarean sections, the number of cesarean sections surplus to $15 \%$ by geographic region was obtained and increased to the normal delivery. The resulting calculation, as a means of payments made for each type of delivery (normal and cesarean section) and the difference between the values defined the estimated reduction of spending.

In Table 3, it is possible to identify the value of reduced spending in cesarean sections considering the WHO recommendation. The largest reduction occurred in the two regions with the largest numbers of cesarean sections (Northeast and Southeast), resulting in $69.6 \%$ of all considered reduction.

\section{DISCUSSION}

The data above confirm a study by Faúndes and Cecatti ${ }^{1}$, which pointed to a progressive increase in the rate of cesarean sections since the 1970s. As pointed out in the analysis of the health situation in Brazil12 in the year 2013, there was an increasing

TABLE 1: NUMBER OF VAGINAL DELIVERIES AND CESAREAN SECTIONS PER BRAZILIAN GEOGRAPHIC REGION, IN 2015.

\begin{tabular}{l|r|r|r|r|r|r}
\hline Type of Delivery & \multicolumn{1}{c}{ South } & \multicolumn{1}{l}{ Southeast } & Midwest & Northeast & North & Total \\
\hline Vaginal delivery & 44,163 & 190,973 & 42,648 & 208,492 & 90,722 & 576,998 \\
\hline Vaginal delivery in high-risk pregnancy & 3,074 & 17,327 & 1,603 & 23,983 & 4,171 & 50,158 \\
\hline Vaginal delivery in delivery center & 0 & 688 & 0 & 0 & 0 & 688 \\
\hline Total - normal delivery & 47,237 & 208,988 & 44,251 & 232,475 & 94,893 & 627,844 \\
\hline cesarean section & 25,061 & 74,375 & 27,906 & 95,123 & 45,505 & 267,970 \\
\hline cesarean section in high-risk pregnancy & 4,394 & 25,500 & 3,352 & 31,259 & 8,713 & 73,218 \\
\hline cesarean section with tubal sterilization & 1,358 & 6,834 & 1,531 & 3,708 & 1,844 & 15,275 \\
\hline Total - cesarean sections & 30,813 & 106,709 & 32,789 & 130,090 & 56,062 & 356,463 \\
\hline Overall Total & 78,050 & 315,697 & 77,040 & 362,565 & 150,955 & 984,307 \\
\hline
\end{tabular}

Source: Ministry of Health - Hospital Information System of the Brazilian National Health System (SIH /SUS).

TABLE 2: TOTAL AMOUNT PAID (US\$) IN HOSPITALIZATIONS FOR VAGINAL DELIVERIES AND CESAREAN SECTIONS PER BRAZILIAN REGION, IN 2015

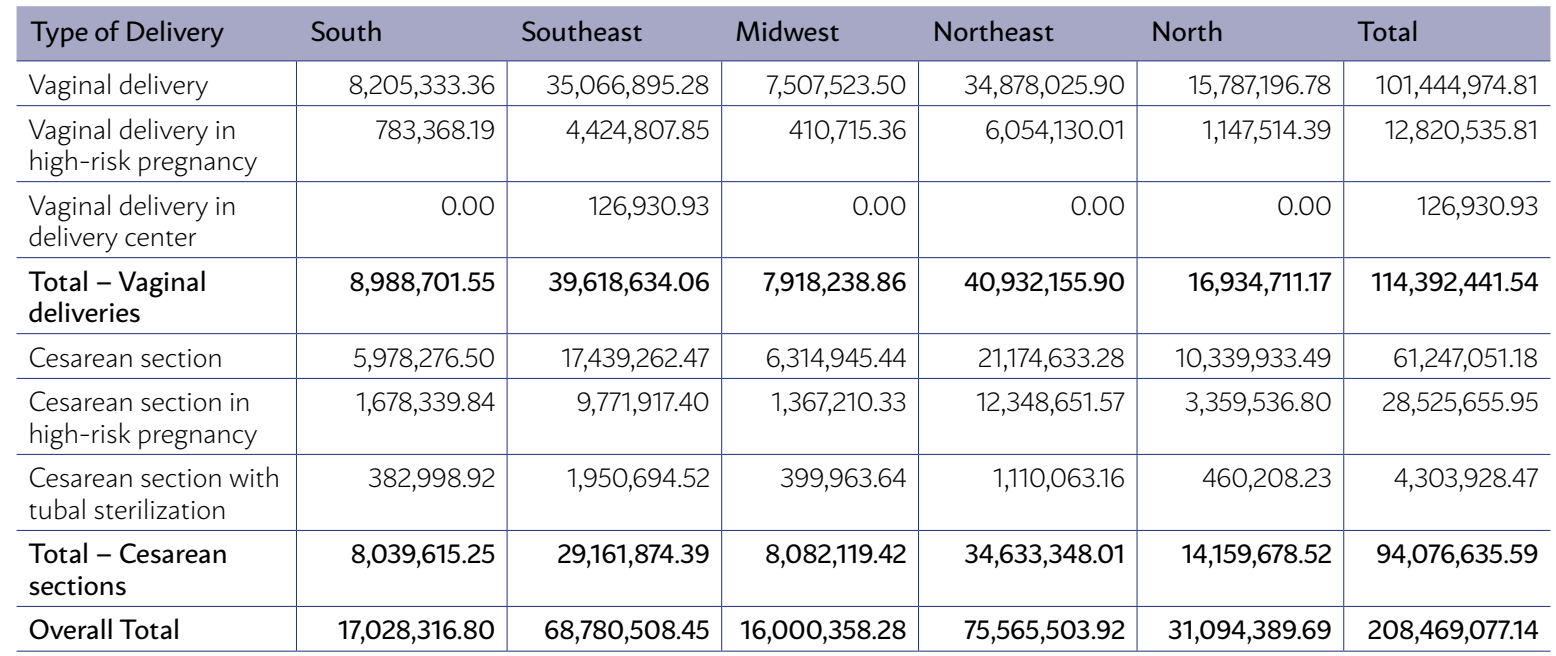

Source: Ministry of Health - Hospital Information System of the Brazilian National Health System (SIH /SUS). 
TABLE 3: ESTIMATED COST REDUCTION (US\$) PER BRAZILIAN REGION, IN 2015

\begin{tabular}{|c|c|c|c|c|c|c|}
\hline & South & Southeast & Midwest & Northeast & North & Total \\
\hline $\begin{array}{l}\% \text { Surplus of cesarean } \\
\text { sections }\end{array}$ & 24 & 19 & 28 & 21 & 22 & \\
\hline $\begin{array}{l}\text { Excess number of cesare- } \\
\text { an births }\end{array}$ & 18,732 & 59,982 & 21,571 & 76,139 & 33,210 & 209,634 \\
\hline Excess amount paid (US\$) & $5,635,474.75$ & $18,057,292.83$ & $6,438,394.49$ & $23,273,415.95$ & $9,546,506.29$ & $62,951,084.30$ \\
\hline $\begin{array}{l}\text { Value to be added to } \\
\text { vaginal delivery (US\$) }\end{array}$ & $4,126,973.51$ & $12,466,099.33$ & $4,662,106.81$ & $15,978,595.59$ & $7,200,579.15$ & $44,434,354.39$ \\
\hline Reduction (US\$) & $1,508,501.23$ & $5,591,193.50$ & $1,776,287.68$ & $7,294,820.36$ & $2,345,927.14$ & $18,516,729.91$ \\
\hline
\end{tabular}

Source: Estimates calculated by the authors, 2016.

trend of cesarean sections in all regions of the country between 2000 and 2012, especially in the Northeast region.

Of the total number of cesarean deliveries, 15.275 (4.3\%) involved tubal ligation. It should be noted that surgical sterilization as a contraceptive method is only permitted if proven necessary by successive previous cesarean sections, according to the Law 2,263 of January $12,1996^{13}$.

Faúndes and Cecatti ${ }^{1}$ pointed to the use of cesarean deliveries as a form of tubal ligation in 1991, at a time when surgical sterilization was not formally prohibited in Brazil. A study conducted in the Metropolitan Region of Campinas, São Paulo, between October 2004 and February 2005, pointed out that, even after surgical sterilization was regulated in 1996, the majority of the cases remained in the delivery, involving a cesarean section ${ }^{14}$.

The Northeast and Southeast regions were the ones that performed the most normal deliveries, with the lowest mean AIH values for the procedures. At the same time, they also performed the highest number of cesareans, with the highest mean AIH values. The Northeastern region presented the highest variation among the means of payment of $\mathrm{AIH}$, with a difference of R\$298.84 (US\$95.81), while the North region had the lowest average variation, with only $R \$$ 220.33 (US\$ 70.64).

Usual risk pregnancies accounted for 860,931 (87.5\%) of all deliveries in 2015, while high-risk pregnancies accounted for 123,376 (12.5\%) deliveries. Of these, 50,158 (5.1\%) normal high-risk deliveries and 73,218 (7.4\%) high-risk cesarean deliveries. High-risk pregnancies were responsible for the highest average AIH paid in all Brazilian regions, despite the disparities in values.

These data are consistent with Zorzetto ${ }^{6}$, who estimated in 2006 that approximately 560,000 unnec- essary cesareans were performed in Brazil, consuming almost R\$ 84 million (US\$38,7 million). Faúndes and Cecatti ${ }^{1}$ stated that the cost of a surgical delivery was easier to identify when compared to a vaginal delivery due to the longer stay and the use of drugs and other consumables, in addition to numerous cases of iatrogenic prematurity. Finally, WHO states that (unnecessary) cesarean sections generate significant additional expenditure for already overburdened health systems ${ }^{15}$.

\section{CONCLUSION}

The findings indicate that cesarean sections are above average recommended in all regions, particularly the Northeast and Southeast regions, as they represent the largest reduction in estimated costs. As would be expected, it was obtained a positive relationship between the length of stay in hospital basis and the amount reimbursed by SUS: the longer the stay, the greater the final amount paid.

When it is accepted the birth cesarean section levels recommended by the WHO, there would be a potential reduction of \$ 57,7 million Brazilian currency (or US\$18,5 million).

A limiting factor to this research was not to have found similar studies to compare with our data. However, regardless of this fact, the value found could be allocated to improve access to maternal and child care, as well as improve hospital structures and create new normal delivery centers in order to encourage natural / normal delivery in all regions of Brazil.

In summary, there is a need for change, restructuring the pattern of births in Brazil. The situation was already pointed out in previous studies and full of knowledge of agencies such as the Ministry of Health and the National Regulatory Agency for Private Health Insurance and Plans. 


\section{RESUMO}

OBJETIVO: Descrever o montante de recursos pagos pelo Sistema Único de Saúde por procedimentos de parto normal e cesárea, segundo as regiões brasileiras, em 2015, estimando a redução de gastos caso a recomendação da Organização Mundial da Saúde quanto à prevalência de partos cesáreas (10\% a 15\%) fosse seguida.

MÉTODOS: Emprego de dados secundários presentes no Sistema de Informações Hospitalares do Sistema Único de Saúde. As variáveis consideradas foram: tipo de parto (cesárea e normal), região geográfica de ocorrência, tempo de permanência hospitalar e valor da Autorização de Internação Hospitalar paga, em 2015.

RESULTADOS: No ano de 2015 ocorreram 984.307 internações para realização de parto nas cinco regiões brasileiras, sendo 36,2\% de partos por cesárea. Nordeste e Sudeste foram as duas regiões que se destacaram, com os maiores números de partos normais e cesáreas. A média geral em dias de internação para parto nas cinco regiões foi de 3,2 dias. Foram pagos aproximadamente R\$650 milhões (US\$ 208,5 milhões), 45\% desse total em partos cesáreas. Caso o parâmetro máximo proposto pela Organização Mundial da Saúde fosse considerado, haveria uma redução potencial de gastos na ordem de R\$ 57,7 milhões (US\$ 18,5 milhões).

CONCLUSÕES: Os partos cesáreas estão acima do parâmetro recomendado em todas as regiões brasileiras. As regiões Nordeste e Sudeste se destacaram por representar potencialmente a maior redução na estimativa de gastos (69,6\% de toda a redução considerada).

PalaVras-Chave: Políticas, Planejamento e Administração em Saúde. Políticas Públicas de Saúde. Economia da saúde. Parto normal. Cesárea.

\section{REFERENCES}

1. Faúndes $A$, Cecatti JG. A operação cesárea no Brasil. Incidência, tendências, causas, consequências e propostas de ação. Cad Saúde Pública. 1991;7(2):150-73

2. Brasil. Ministério da Saúde. Secretaria da Ciência, Tecnologia e Insumos Estratégicos. Comissão Nacional de Incorporação de Tecnologias no SUS. Diretrizes de atenção à gestante: a operação cesariana. Protocolo. Brasília: Ministério da Saúde; 2016.

3. Villar J, Valladares E, Wojdyla D, Zavaleta N, Carroli G, Velazco A, et al; WHO 2005 global survey on maternal and perinatal health research group. Caesarean delivery rates and pregnancy outcomes: the $2005 \mathrm{WHO}$ global survey on maternal and perinatal health in Latin America. Lancet. 2006;367(9525):1819-29.

4. Brasil. Conselho Federal de Medicina. Resolução 2144, de 17 de março de 2016. É ético o médico atender à vontade da gestante de realizar parto cesariano, garantida a autonomia do médico, da paciente e a segurança do binômio materno fetal. Diário Oficial [da] República Federativa do Brasil, Poder Executivo, Brasília, DF, 2016 jun 22. Seção 1, p.138.

5. Leal MC, Gama SGN, Bittencourt SDA, Theme Filha MM, Dias MAB, Domingues RMSM, et al. Cesarianas desnecessárias: causas, consequências e estratégias para sua redução. In: Pereira, RC, Silvestre RM, orgs. Regulação e modelos assistenciais em saúde suplementar: produção científica da Rede de Centros Colaboradores da ANS - 2006/2008. Brasília: Organização Pan-Americana da Saúde; 2009. p.383-415.

6. Zorzetto R. Escolha errada. Pesqui FAPESP 2006;124:38-44. [cited 2018 Feb 11] Available from: http://www.cepia.org.br/doc/mulheres.pdf

7. Brasil. Agência Nacional de Saúde Suplementar - ANS. Projeto parto adequado. [Internet]. 2015 [cited 2016 Maio 07]. Available from: <http://www. ans.gov.br/prestadores/projeto-parto-adequado>.

8. Brasil. Agência Nacional de Saúde Suplementar - ANS. Resolução Normativa - RN n- 368, de 06 de janeiro de 2015. Dispõe sobre o direito de acesso à informação das beneficiárias aos percentuais de cirurgias cesáreas e de partos normais, por operadora, por estabelecimento de saúde e por médico e sobre a utilização do partograma, do cartão da gestante e da carta de informação à gestante no âmbito da saúde suplementar. Diário Oficial [da] República Federativa do Brasil, Poder Executivo, Brasília, 2015 jan 07. Seção 1, p.38.

9. Brasil. Ministério da Saúde. DATASUS [Internet]. Internações por região segundo capítulo CID-10. Brasília: Ministério da Saúde; 2015. [cited 2016 Maio 13]. Available from: <http://tabnet.datasus.gov.br/cgi/tabcgi.exe?sih/cnv/nruf.def>

10. Brasil. Agência Nacional de Saúde Suplementar - ANS. Dimensão "atenção à saúde" 2a fase: taxa de parto cesárea [Internet]. Brasília 2007. [cited 2016 jan 02]. Available from: <http://bvsms.saude.gov.br/bvs/publicacoes/qualificacao_saude_sup/pdf/Atenc_saude2fase.pdf>.

11. Organização Mundial da Saúde. Maternidade segura. Assistência ao parto normal: um guia prático. Genebra: OMS; 1996.

12. Brasil. Ministério da Saúde. Secretaria de Vigilância em Saúde. Departamento de Análise de Situação de Saúde. Como nascem os brasileiros. In: Saúde Brasil 2013: uma análise da situação de saúde e das doenças transmissíveis relacionadas à pobreza. Brasília: Ministério da Saúde; 2014. p.22-39.

13. Brasil. Lei no 9263, de 12 de janeiro de 1996. Regula o $\S 70$ do art. 226 da Constituição Federal, que trata do planejamento familiar, estabelece penalidades e dá outras providências. Diário Oficial [da] República Federativa do Brasil, Poder Executivo, Brasília, 1996 jan 12. Seção 1, p.561.

14. Carvalho LEC, Osis MJD, Cecatti JG, Bento SF, Manfrinatti MB. Esterilização cirúrgica voluntária na Região Metropolitana de Campinas, São Paulo, Brasil, antes e após sua regulamentação. Cad Saúde Pública. 2007;23(12):2906-16.

15. Organização Mundial da Saúde. Declaração da OMS sobre taxas de cesáreas [Internet]. 2015. [cited 2016 jan 05]. Available from: <http:// apps.who.int/iris/bitstream/10665/ 161442/3/WHO_RHR_15.02_por.pdf?ua $=1 \&$ ua $=1$. . 